\title{
Missed Injury in Patients with Severe Traumatic Brain Injury Complicated by Multiple Trauma
}

\author{
Çoklu Travmayla Komplike Şiddetli Beyin Yaralanması Hastalarında \\ Atlanmıs Yaralanmalar
}

Feng YI, Shi ZHONGHUA, Wang YUHAI, Dong JIRONG, Cai XUEJIAN

101th Military Hospital of PRC, Army's Traumatic Brain Injury Center, Wuxi, P.R. China

Correspondence address: Wang YUHAI / E-mail: yuhaiwangcn@163.com

\section{ABSTRACT}

AIM: The aim of this study was to investigate retrospectively the multiple injuries prone to be missed in 432 cases.

MATERIAL and METHODS: The cases were divided into two groups, i.e., whether the missed injury was found during admission or follow up. The mean ISS value, ratio of patients of cases with GCS $<8$, and mortality were calculated and compared. The incidences of missed diagnosis of various body parts were calculated and compared with one another to identify the multiple injuries prone to be missed during the diagnosis for severe traumatic brain injury patients accompanied by multiple trauma.

RESULTS: Among the 432 patients, 54 patients had missed injuries. The mean ISS value and the ratio of patients of cases GCS $<8$ in the missed group were higher compared with those in the non-missed group. The missed diagnosis ratio of various body parts had significant differences. Injuries in the optic nerve and abdomen were the more often missed injuries in the diagnosis.

CONCLUSION: The multiple trauma severity and coma degree impact diagnoses for severe TBI complicated by multiple injuries is highly accurate. The early diagnosis of injury is of the highest importance so that the injury may be treated immediately.

KEYWORDS: Severe traumatic brain injury, Multiple injury, Missed diagnosis

öz

AMAÇ: Bu çalışmanın amacı 432 hastada atlanması muhtemel çoklu yaralanmaları retrospektif olarak incelemektir.

YÖNTEM ve GEREÇLER: Vakalar, atlanmış yaralanmanın hastaneye yatma veya takip sırasında bulunmasına göre iki gruba ayrılmıştır. Ortalama ISS değeri, GCS <8 olan hastaların oranı ve mortalite hesaplanmış ve karşılaştııılmıştır. Çeşitli vücut kısımlarında atlanmış tanı insidansları hesaplanmış ve çoklu travma ile birlikte şiddetli travmatik beyin yaralanması olan hastalarda tanı koyma sırasında atlanması muhtemel çoklu yaralanmaları tanımlamak için birbiriyle karşılaştırılmıştır.

BULGULAR: 432 hasta içinde 54 hastada atlanmış yaralanmalar bulunmuştur. Atlanmış grupta ortalama ISS değeri ve GCS <8 olan hastaların oranı atlanmamış grupta olanlara göre daha yüksektir. Çeşitli vücut kısımlarında atlamış tanı oranı açısından önemli farklılıklar bulunmuştur. Optik sinir ve karın yaralanmaları tanı koyarken en sık atlanan yaralanmalardır.

SONUÇ: Çoklu yaralanmalarla komplike şiddetli travmatik beyin yaralanması için çoklu travma şiddeti ve koma derecesi etkisi tanıları yüksek ölçüde doğrudur. Yaralanmaya erken tanı konması yaralanmanın hemen tedavi edilebilmesi açısından çok önemlidir.

ANAHTAR SÖZCÜKLER: Şiddetli travmatik beyin yaralanması, Çoklu yaralanma, Atlanmış tanı

\section{INTRODUCTION}

In recent years, the incidence of traumatic brain injury (TBI) has increased with the development of the transportation industry in China, bringing high morbidity and mortality. Severe TBI is difficult to deal with, especially when accompanied by multiple trauma. Despite intensified and standardised diagnostic procedures prescribed by trauma centres, injuries are still sometimes missed in severely injured patients (13). Multiple injuries accompanied by TBI have an incidence of greater than $60 \%$, and thus, the treatment of multiple traumas that mainly manifest with TBI is a new, important, and urgent issue. Severe TBI patients in coma (GCS 3-8) cannot participate in complain physical examination. In such cases, avoidable death, disability of pain or indisposition, and can not cooperate in injury are prone to be missed in the diagnoses.

\section{MATERIAL and METHODS}

In this study, a retrospective review was conducted in 432 patients who were admitted in the Army's traumatic brain injury center between January 2001 and August 2011, with follow ups until February 2012. The selected cases had discharged diagnoses of severe traumatic brain injury and multiple trauma with injury severity score (ISS) $>=17(3,4)$. All patients are locals who suffered from car accidents, slips or falls, assaults, or machine injuries. This study was conducted 
in accordance with the declaration of Helsinki and with the approval of the Ethics Committee of the 101th Military Hospital of PRC. All participants gave written and informed consents.

In this study, 432 patients were divided into two groups. The first group is the missed group ( $n=54)$, where missed injury was found during admission or during follow up, 115 injury parts are concerned, and the delayed time prior to diagnosis ranged from 3 hours to 47 days. The second group is the nonmissed group ( $n=378$ ), where no missed injury was found during admission or during follow up.

The diagnostic criteria of missed injury are as follows: (1) Treated within 24 hours after hospitalisation through a comprehensive assessment, and no multiple injury was found; (2) Suspicion and inspection after sudden deterioration in the condition or a deadly injury was accidentally found during intraoperative detection; (3) No multiple injuries were found in pre-hospital rescue or hospital records; and (4) Injured parts were found in the follow up, and no documented history of injury was found.

The exclusion criteria are as follows: (1) Relevant records were found and great deal of advice was gathered from the emergency or hospital records, but the critical condition was not further examined and diagnosed; and (2) No abnormalities in direct relation to trauma, emergency, and admission examination were found, but timely detection of delayed organ rupture was performed in the consequent examination.

All data were analysed using the SPSS for Windows 11.0 statistical software.

\section{RESULTS}

Comparing the ISS, ratio of patients of cases GCS $<8$, and mortality of the two groups, the mean ISS value of the missed group (41.51) was found to be higher than that of the nonmissed group (29.59) $(F=66.56, P<0.01)$. The cases of $G C S<$ 8 in the missed group accounted for $64.8 \%$, which was higher than that in the non-missed group with $35.98 \%\left(X^{2}=15.24\right.$, $P<0.01)$. The mortality of the missed group (18.52\%) was higher than that of the non-missed group $(7.67 \%)\left(X^{2}=5.51, P\right.$ $<0.05)$. The results are shown in Table I.

The missed injuries in various body parts and the prognosis are listed in Table II. The missed diagnosis ratio of six body parts showed significant differences $\left(X^{2}=32.26, P<0.01\right)$. Four patients died among the 20 cases of missed diagnosis in the chest at 26 locations. None of the four patients received chest examination upon admission, and three of them experienced a drop in blood pressure during brain surgery. For the consequent B ultrasonic found severe hydrothorax, one patient experienced a drop in blood pressure $24 \mathrm{~h}$ after admission. The chest X-ray indicated complicated rib fractures and hemothorax. The diagnosis of abdominal organ injury was missed in 14 patients, among which 6 died. Among the 14 patients, 12 patients did not receive B-ultrasonic or abdominal
CT examination upon admission because of different reasons. Moreover, among the 14 patients, 2 had hepatic ruptures, 7 had splenic ruptures, 1 had hepatic plus splenic rupture, 2 had intestinal ruptures, 1 had renal rupture, and 4 had hemoperitoneum but without rupture. Among the 10 cases with pelvis fracture, 3 had missed diagnoses. Among the 23 cases with spinal cord injuries, 4 had missed diagnoses, one of which died because of atlantoaxial joint dislocation. Among the 211 cases of limb fractures, 16 had missed diagnoses, one of which became disabled because of hip joint injury. Finally, among the 3 optic nerve injuries, 2 had missed diagnoses.

\section{DISCUSSION}

Multiple injuries complicated by severe TBI have always been missed during diagnoses and delayed in processing, leading to increased mortality and disability rates (5). Doctors experienced difficulties in assessing the condition of severe TBI patients in coma because of the lack of chief complaints and subjective symptoms. Despite the efforts exerted by doctors, a considerable number of cases is still missed in diagnoses, resulting in the delay of treatment, prolonged hospitalisation time, and even severe disability or death. Moreover, $8.1 \%-19.4 \%$ of missed diagnosis rates for multiple injuries $(5,12)$ was reported to be mainly caused by incomplete assessment. In this study, a missed diagnosis rate of $12.50 \%$, which is similar to the former, was found. Trauma severity and coma degree significantly affect the accuracy of the diagnoses. Patients with missed injuries had higher ISS than patients without missed injuries. Moreover, patients with missed injuries are more likely to have lower GCS scores than patients without missed injuries, as shown in the results of former reports $(5,10)$.

Deadly missed injuries are particularly prevalent in the ventrum $(5,16)$ because of severe TBI patients that need emergency rescue, and the hidden deadly injuries are always overlooked. The consequences of such can be serious even if the deadly missed injuries are often attended to within two to three hours post-injury diagnosis after a sudden deterioration. However, medical treatment is too late most of the time. In this study, 10 patients died and 7 patients ( 9 missed injury) accelerated the death. The missed injuries and death had a correlation of $70 \%$, which was close to the formerly reported correlation of $62 \%$ (12). In this study, all deadly injuries were found in the abdomen or chest areas, in which the abdominal injury obtained the highest missed diagnosis rate of 35\% and killed six patients (Table I). Thus, a ventrum CT scan as part of the routine is highly recommended for patients in coma. In addition, the hollow viscus was found to be highly vulnerable to abdominal injury. In this study, two cases of intestinal ruptures were missed during diagnoses because of the following reasons: (1) Small perforation of hollow viscus had slow progression, and thus, clinical signs were not obvious; (2) No significant bleeding and no definite iconography characteristics, such as subphrenic free gas, were found; and (3) No chief complaint of "pain," which is the most typical symptom, caused difficulties in the early diagnosis. Severe TBI 
Table I: Comparison of Clinical Data Between Missed Group and Non-Missed Group

\begin{tabular}{|l|c|c|c|}
\hline Item & Missed group & Non-missed group & Statistical value \\
\hline Mean ISS value & 41.51 & 29.59 & $\mathrm{~F}=66.56, \mathrm{P}<0.01$ \\
\hline Cases of GCS $<8$ & $64.8 \%$ & $35.98 \%$ & $\mathrm{X}^{2}=15.24, \mathrm{P}<0.01$ \\
\hline Cases of GCS $<8$ & $64.8 \%$ & $35.98 \%$ & $\mathrm{X}^{2}=15.24, \mathrm{P}<0.01$ \\
\hline Mortality & $18.52 \%$ & $7.67 \%$ & $\mathrm{X}^{2}=5.51, \mathrm{P}<0.05$
\end{tabular}

Table II: Missed Injury of Different Body Parts and the Prognosis

\begin{tabular}{|c|c|c|c|c|c|c|c|}
\hline \multicolumn{2}{|l|}{ Parts of missed } & Total & Missed & Missed & Died & Disability & Diagnosis \\
\hline \multicolumn{2}{|l|}{ injuries } & cases & diagnosis & diagnosis & & caused by & Delayed time \\
\hline & & & cases & rate $(\%)$ & & missed & \\
\hline & & & & & & diagnosis & \\
\hline \multirow[t]{4}{*}{ Deadly injuries } & Chest & 153 & 20 & 13.07 & 4 & 0 & $3 h-9 d$ \\
\hline & Abdominal organs & 40 & 14 & 35.00 & 6 & 0 & $2 h-20 d$ \\
\hline & Spinal cord & 23 & 4 & 17.39 & 0 & 2 & $1-8 d$ \\
\hline & Pelvis & 10 & 3 & 30.00 & 0 & 0 & $14-26 d$ \\
\hline \multicolumn{8}{|l|}{ Disable injuries } \\
\hline & Limbs & 211 & 16 & 7.58 & 0 & 1 & $2-47 d$ \\
\hline & Optic nerve & 3 & 2 & 66.67 & 0 & 1 & $2 d-3 m$ \\
\hline
\end{tabular}

The missed diagnosis ratio of 6 body parts showed a significant difference $\left(X^{2}=32.26, P<0.01\right)$.

patients inflicted with hematuria suffered fractures in their lower ribs, lumbar spine, or pelvis (15). More attention should be paid to signs of injuries in the abdomen, such as peritoneal irritation sign, decreased bowel sounds, and abdominal muscles guarding. Abdominal paracentesis, B ultrasonic, or CT scan is recommended when hollow viscus injury is suspected. Moreover, exploratory laparotomy should be conducted when possible because the hollow viscus injury exhibit persistent symptoms, but with no evidence. Consecutive observations, repeated physical investigations, and auxiliary examinations should be administered to patients who are suspected to suffer from abdominal cavity organ rupture. Such patients will manifest signs of aggravating peritoneal irritation or tardus free gas under the diaphragm. However, if such signs are not obvious, abdominal CT/ plain film after barium meal should be conducted to confirm the injury.

Disabling missed injuries are particularly prevalent in occult parts, such as the optic nerve, pelvis, and spinal cord. The inability of critically ill patients to move immensely affects their diagnoses. The lack of obvious signs of the injuries, particularly for patients in coma, makes early diagnosis difficult, causing the delay in the discovery of the injuries that may lead to severe disability (9). The rate of missed diagnosis of thoracolumbar spine injury of $24 \%$ was found in multiple trauma patients (1). In this study, 23 patients had spinal cord injuries, 4 of which suffered from missed diagnosis that amounted to $17.39 \%$, which was not the highest incidence. However, two of the four patients were disabled, showing the high possibility of disability after missed diagnosis. We believe that the medical history of injury mechanism should be carefully asked from such patients. Spinal cord X-ray examination is necessary for patients who suffered from whiplash and falling injuries. Pathological reflex and abnormal muscle tone or tendon reflexes, which cannot be explained by TBI, should be suspected from the existence of paralysis. Thus, CT scan of Co-C3, which is superior to plain films, should be conducted for the early detection of upper cervical spine injury $(7,8,14)$. Therefore, in addition to the initial head scan, a CT scan of Co-C3 should be performed as part of the routine for patients suspected of neck injury. Optic nerve injury is also an easily ignored case, especially in brain hernia patients. In this study, three patients had optic nerve injury, two of which had missed diagnosis (66.67\%), leading to the disability of a patient. Orbital CT three-dimensional reconstruction that focuses on the narrow of portion of the optic canal should be performed when Marcus-Gunn pupil $(2,6)$ cannot be explained by the presence of TBI to ensure definite optic canal compression or haematoma formation. Moreover, the decompression of the optic canal should be performed as soon as possible in such case (11).

The occurrence of missed injuries for severe TBI patients complicated by multiple traumas increased with the severity of multiple trauma. Thus, the early diagnosis of injuries is highly important so that the injuries may be treated immediately. Moreover, the disabling injuries should be immediately diagnosed when the deadly injury is controlled. 


\section{REFERENCES}

1. Anderson S, Biros MH, Reardon RF: Delayed diagnosis of thoracolumbar fractures in multiple-trauma patients. Acad Emerg Med 3:832-839, 1996

2. Ansari $\mathrm{MH}$ : Blindness after facial fractures: A 19-year retrospective study. J Oral Maxillofac Surg 63:229-237, 2005

3. Baker SP, O'Neill B, Haddon W Jr, Long WB: The injury severity score: A method for describing patients with multiple injuries and evaluating emergency care. J Trauma 14:187-196, 1974

4. Brenneman FD, Boulanger BR, McLellan BA, Redelmeier DA: Measuring injury severity: Time for a change? J Trauma 44:580-582, 1998

5. Buduhan G, McRitchie DI: Missed injuries in patients with multiple trauma. J Trauma 49:600-605, 2000

6. Chang EL, Bernardino CR: Update on orbital trauma. Curr Opin Ophthalmol 15:411-415, 2004

7. Diaz JJ Jr, Gillman C, Morris JA Jr, May AK, Carrillo YM, Guy $\mathrm{J}$ : Are five-view plain films of the cervical spine unreliable? A prospective evaluation in blunt trauma patients with altered mental status. J Trauma 55:658-663, 2003

8. Harris TJ, Blackmore CC, Mirza SK, Jurkovich GJ: Clearing the cervical spine in obtunded patients. Spine 33:1547-1553, 2008

9. Hebert JS, Burnham RS: The effect of polytrauma in persons with traumatic spine injury. A prospective database of spine fractures. Spine 25:55-60, 2000
10. Janjua KJ, Sugrue M, Deane SA: Prospective evaluation of early missed injuries and the role of tertiary trauma survey. $J$ Trauma 44:1000-1006, 1998

11. Mine S, Yamakami I, Yamaura A, Hanawa K, Ikejiri M, Mizota A, Adachi-Usami E: Outcome of traumatic optic neuropathy. Comparison between surgical and nonsurgical treatment. Acta Neurochir (Wien) 141:27-30, 1999

12. Okello CR, Ezati IA, Gakwaya AM: Missed injuries: A Ugandan experience. Injury 38:112-117, 2007

13. Pehle B, Kuehne CA, Block J, Waydhas C, Taeger G, NastKolb D, Ruchholtz S: The significance of delayed diagnosis of lesions in multiply traumatised patients. A study of 1, 187 shock room patients. Unfallchirurg 109:964-974, 2006

14. Schenarts PJ, Diaz J, Kaiser C, Carrillo Y, Eddy V, Morris JA Jr: Prospective comparison of admission computed tomographic scan and plain films of the upper cervical spine in trauma patients with altered mental status. J Trauma 51:663-668, 2001

15. Sirlin CB, Brown MA, Deutsch R, Andrade-Barreto OA, Fortlage DA, Hoyt DB, Casola G: Screening US for blunt abdominal trauma: Objective predictors of false-negative findings and missed injuries. Radiology 229:766-774, 2003

16. Sung CK, Kim KH: Missed injuries in abdominal trauma. J Trauma 41:276-282, 1996 